\title{
疑似潮汐変動下で浸透する有機泥による 透水係数の変動 \\ PERMEABILITY CHANGE OF SAND BEDS DUE TO SEDIMENT MIGRATION UNDER SEEPAGE FLOW WITH OSCILLATING WATER HEAD CONDITION
}

\author{
TOUCH NARONG ${ }^{1}$ ・福井勝吾 ${ }^{2} \cdot$ 中下慎也 $^{3} \cdot$ 福岡捷二 $^{4} \cdot$ 日比野忠史 ${ }^{5}$ \\ Narong TOUCH, Shogo FUKUI, Shinya NAKASHITA, Shoji FUKUOKA and Tadashi HIBINO \\ 1学生会員 工修 広島大学 工学研究科 JSPS特別研究員DC (テ739-8527 広島県東広島市鏡山1-4-1) \\ 2学生会員 広島大学 工学研究科 社会基盤環境工学（テ739-8527 広島県東広島市鏡山1-4-1） \\ 3正会員 工博 広島大学助教 工学研究院 社会環境空間（广739-8527 広島県東広島市鏡山1-4-1） \\ 4フェロー工博 中央大学研究開発機構教授（广112-8551 東京都文京区春日1-13-27） \\ 5正会員 工博 広島大学准教授 工学研究院 社会環境空間（テ739-8527 広島県東広島市鏡山1-4-1）
}

In this study, column experiments were conducted to understand the release behavior of sediment from the sand columns. Further, a sediment filtration experiment was conducted under seepage flow with oscillating water head condition to investigate the permeability changes due to sediment migration. The results suggest that the permeability of the sand columns increased after making upward current, and increasing tendencies depended on the type of sediment. In addition, changes in piezo-metric head under seepage flow with oscillating water head condition could be simulated based on a conventional model with a relative error of $3 \%$, leading to the prediction of decreases in porosity due to sediment retention. Therefore, changes in permeability of sand beds can be determined if the piezo-metric head is known.

Key Words: Sediment, migration, piezo-metric head, permeability, sand bed, oscillating water head

\section{1.はじめに}

潮汐による地盤内浸透は地盤内での生物生息環境 （水質・泥質）に強い影響を及ぼすことが明らかに なっている1．地下水流れが有機泥（シルト・粘土粒子 に有機物が付着した粒径 1〜100 $\mu \mathrm{m}$ 細粒子）を輸送 できる干潟は地盤浄化を促進するのみならず，地盤内で の生物棲息環境を形成する等の機能を有している. 有機 泥は, 地下水流れが十分にある干潟地盤では有用生物に 対する餌の供給源等となる2), 3)が，矢板等によって地下 水の運動が制限されると干潟地盤上や間隙内に停滞し, アサリ等の有用生物の棲息を阻害することが多い．

汽水域での地盤内浸透における物質輸送に関する 研究は過去の数十年間に積極的に行われ, 浸透流が地盤 内一の物質輸送を促進することを明らかにしている. 例えば, Sintonら ${ }^{4}$ は地下水輸送モデルAT123Dを Parameter Estimation (PEST) 最適化ルーチンと併用して 沖積の砂礫帯水層におけるバイオコロイド粒子の輸送 速度, 輸送量等の推測を行い, バイオコロイド粒子の 輸送に及ぼす間隙目詰り（pore size exclusion）の影響を 明らかにした。 Kim ら ${ }^{5}$ やBekhitら ${ }^{6}$ は地盤内浸透に おける污染物質・ コロイド粒子・バクテリア・有機物 の物理, 化学, 生物的な過程を同時に考慮した運動学的 モデルを提案し, 実験結果が提案モデルで再現できる こと, さらに, バクテリアおよび溶存態有機物は污染 物質の輸送速度を促進することが明らかにされた。 しかし, これらの研究が対象している粒子と比べて, 有 機泥は粒子形状や化学性状等の異なる粒子特性を有して おり7，異なる輸送特性を有すると予想される.

著者らは河川干潟における砂地盤への有機泥の侵入を 再現することを目的として, 表-1に示寸基礎研究により 干潟地盤内における地下水流れを駆動力とする有機泥の 輸送モデルを構築した. これらの研究では, 径深概念を とり入れたポアズイユの法則に新たに砂粒子の体積平均 粒径および有機泥の中央粒径と残留体積を導入した圧力 損失式を提案している. 提案した圧力損失式を用いて 砂柱における一次元浸透流による有機泥の輸送機構が 実験的に明らかにされている.さらに, 既存の輸送モデ ルを単純化した有機泥の一次元残留モデルおよび有機泥 
表-1＼cjkstart砂柱における有機泥の浸透に関する著者らの研究.

\begin{tabular}{|c|c|c|c|}
\hline 発行年 & 条件 & 手法 & 成果 \\
\hline (i) $2010^{8)}$ & \multirow{4}{*}{$\begin{array}{l}\text { •粗砂 } \\
\text { •一次元浸透実験 } \\
\text { •飽和状態 } \\
\text { • 有機泥 }\end{array}$} & $\begin{array}{l}\text { •ポアズイユの法則·径深概念 } \\
\text { •体積平均粒径 }\end{array}$ & $\begin{array}{l}\text { 砂柱内での圧力損失を評価し, 有機泥の残留体積を } \\
\text { 考慮した圧力損失式を提案した. }\end{array}$ \\
\hline (ii) $2011 a^{9)}$ & & $\begin{array}{l}\text { •提案式(文献(i)） } \\
\text { •性状が異なる有機泥の浸透 }\end{array}$ & $\begin{array}{l}\text { 文献(i)で提案した圧力損失式を用いて有機泥の輸送に } \\
\text { 及ぼす有機泥の性状の効果を実験的に定量化した. }\end{array}$ \\
\hline (iii) $2011 b^{10)}$ & & $\begin{array}{l}\text { •提案式(文献(i) }) \\
\text { • 異なる浸透流での浸透 } \\
\text { • 異なる間隙体積での浸透 }\end{array}$ & $\begin{array}{l}\text { 文献(i)で提案した圧力損失式を用いて有機泥の輸送に } \\
\text { 及ぼす浸透流量と間隙体積の効果を実験的に定量化 } \\
\text { した. }\end{array}$ \\
\hline (iv) $2012 a^{11)}$ & & $\begin{array}{l}\text { •一次元残留モデル } \\
\text { •透水係数の低下 }\end{array}$ & $\begin{array}{l}\text { Iwasakiらのモデルに基づいて, 砂柱内での有機泥の } \\
\text { 残留モデルと, 有機泥の残留体積を考慮した透水係数 } \\
\text { の低下モデルを提案した. }\end{array}$ \\
\hline (v) $2012 b^{12)}$ & 二次元浸透流実験 & •提案モデル (文献(iv)) & $\begin{array}{l}\text { 地下水流れによる有機泥浸透への提案したモデル } \\
\text { (文献(iv))の適用性を評価した. }\end{array}$ \\
\hline
\end{tabular}

表-2 有機泥の浸透実験での条件.

\begin{tabular}{|c|c|c|c|c|c|c|c|c|c|c|}
\hline \multirow{2}{*}{ 実験 } & \multirow{2}{*}{\begin{tabular}{|l} 
砂層の間 \\
隙率 [\%] \\
\end{tabular}} & \multirow{2}{*}{$\begin{array}{c}\text { 初期透水 } \\
\text { 係数 }[\mathrm{cm} / \mathrm{s}] \\
\end{array}$} & \multirow{2}{*}{ 浸透条件 } & \multirow{2}{*}{\begin{tabular}{|l} 
初期浸透 \\
流量 $\left[\mathrm{cm}^{3} / \mathrm{s}\right]$ \\
\end{tabular}} & \multicolumn{4}{|c|}{$\begin{array}{l}\text { 有機泥の特性 } \\
\end{array}$} & \multicolumn{2}{|c|}{ 混合水のSS濁度 [mg/L] } \\
\hline & & & & & IL [\%] & POC [mg/g] & PON [mg/g] & $\mathrm{C} / \mathrm{N}$ 比 & 流入 & 流出 \\
\hline (1) -1 & 34.56 & $\begin{array}{c}0.17 \\
\text { (Darcy) }\end{array}$ & $\begin{array}{l}\text { 水位差 : } 5.1 \mathrm{~cm} \\
\text { 流れ方向: 上下方向 }\end{array}$ & 1.30 & 12.60 & 26.54 & 2.61 & 11.86 & 115 & 40 \\
\hline (1) -2 & 34.56 & $\begin{array}{c}0.19 \\
\text { (Darcy) }\end{array}$ & $\begin{array}{l}\text { 水位差 : } 5.5 \mathrm{~cm} \\
\text { 流れ方向: 上下方向 }\end{array}$ & 1.31 & 12.40 & 29.53 & 1.53 & 22.52 & 120 & 27 \\
\hline (2) & 36.15 & \begin{tabular}{|c|}
0.39 \\
(Dupuit- \\
Forchheimer
\end{tabular} & \begin{tabular}{|l|} 
低水位 $: 12 \mathrm{~cm}$ \\
高水位: $12 \sim 22 \mathrm{~cm}$ \\
(50秒の周期で変動)
\end{tabular} & $0 \sim 31.25$ & 9.47 & 33.35 & 3.25 & 11.97 & 253 & 32 \\
\hline
\end{tabular}

注 : $\mathbb{L}$ : 有機物含有率, POC : 炭素含有率, PON : 窒素含有率, 水位は砂層の底面からの高さである. 初期透水係数はマノメーターで測定されたピエゾ水頭の差と初期浸透流量から算出した.

の残留に伴う透水係数の低下モデルが提案されている. 本論文の目的は表-1に示す研究成果に基づき，潮汐 変動に伴う砂地盤内一の有機泥の移動挙動を室内実験に より明らかにすることである.このため，広島県太田川 河口から4 km上流に新しく造成した干潟で経年的に砂 試料をサンプリングし，砂試料に含まれる有機物含有量 （IL），および細粒分含有率の変化を検討した（図-1）. 造成からの3年間に細粒分含有率およびILが経年的に 増加傾向にあり, 有機泥が干潟地盤内一侵入し, 有機泥 の残留量が増大していることが確認できた．本論文では 実干潟での有機泥の地盤内への侵入機構を再現するため, 室内実験により，下方向浸透流で有機泥が残留した砂柱 に上方向浸透流を付与し, 有機泥の流出特性と透水係数 の変化を明らかにする．次に，上下方向に周期的に変動 させ，浸透流による有機泥の残留量を検討するために， 砂層内でのピエゾ水頭変動の推定式を提案する.

\section{2. 室内実験の概要と条件}

\section{（1）室内実験の概要}

干潟地盤内への有機泥の侵入機構は，(1)砂柱からの 有機泥の流出条件，および(2)周期的浸透流による砂層内 への有機泥の侵入特性を検討する2種類の実験により 検討した. 両実験の条件は表-2に示されている.

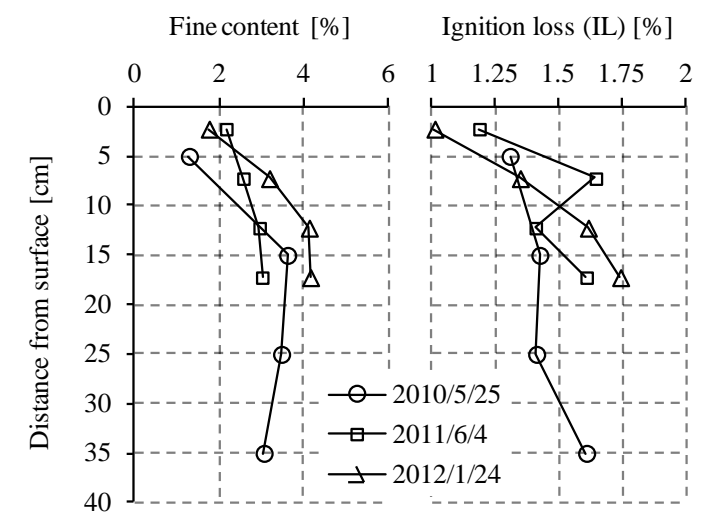

図-1＼cjkstart採収された砂試料の有機物量と細粒分含有率.

(1)実験に用いた砂柱へ有機泥を鉛直方向に浸透させる 装置，および砂柱の作成法はTouchら ${ }^{9)}$ に記載されている. 実験では，砂柱 $(13 \mathrm{~cm})$ に水位差を付与して水道水と 混合した有機泥を上端から砂柱に浸透させ，浸透流量と ピエゾ水頭を測定して間隙内への有機泥の残留に伴う 透水係数の変化を算出する. 浸透開始から1時間後に, 水位差を付与して異なる浸透流速（水位差）で水道水 のみにより鉛直上方向の浸透流を生じさせ，残留有機泥 の流出機構（透水係数の回復）を検討する.

(2)実験は図-2に示した装置で行った。高さ50 cm, 長さ100 cm, 奥行き $25 \mathrm{~cm}$ アアクリル製の実験装置の 側面に，長さ方向に約 $10 \mathrm{~cm}$ の間隔，高さ方向に $4 \mathrm{~cm}$ の 
間隔でマノメーターが取り付けられている，水位差を変 化させる（砂層の表面〜20 cmまで可能）ことで，浸透 流量を制限できる. 砂層 $(25 \mathrm{~cm} \times 25 \mathrm{~cm} \times 60 \mathrm{~cm})$ は水 中に砂材料を投入して作成される．砂層の両端には 100 $\mu \mathrm{m}$ メッシュのネットを透水壁として用いた. (2)実験で は，下流側境界水位を砂層の底面から12 cm（一定）に 維持し，上流側境界水位を12〜23 cmまで約50秒の周期

（図-3）で変化させ，混合水（有機泥を種々の濃度で水 道水と混合）を上流側水槽から浸透させた。 浸透時間の 経過とともにピエゾ水頭，および流入・流出する混合水 の濁度を濁度センサー（OPTEX, TD-M500）で測定した。 上流側境界水の変動に伴う砂層内でのピエゾ水頭をマ， メーターと同時に間隙水圧センサー（SSK, P310A-02） で測定した. 間隙水圧センサーは混合水流入断面の直前 $(x=0)$ ，および砂層内 $(x=10,20 \mathrm{~cm})$ に設置した.

\section{（2）実験に用いた砂および有機泥の特性}

図-4に有機泥の浸透実験に使用した砂，および有機泥 の粒度曲線が示されている. 砂の粒度曲線はふるい分け 試験（JIS A 1204），有機泥の粒度曲線はレーザー回折 式粒度分布計（島津：SALD-2000J）で測定を行った。 実験では，75 $\mu \mathrm{m}$ 以下の細粒子を取り除いた砂を使用 しており, 浸透粒子に関しては75 $\mu \mathrm{m}$ のふるいを通過

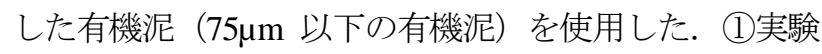
に使用した砂は太田川放水路中流域（河口から5.5 km) にある現地干潟で採取したものであり，体積平均粒径は $0.470 \mathrm{~mm}$, 砂の粒子密度は $2.55 \mathrm{~g} / \mathrm{cm}^{3}$ である. また, (2)実験に用いた砂は市販砂であり，体積平均粒径は $0.593 \mathrm{~mm}$, 砂の粒子密度は2.65 g/ $\mathrm{cm}^{3}$ である. 一方, 浸透させる有機泥の中央粒径は約 $20 \mu \mathrm{m}$ であり, 沈降 速度から算出した有機泥の粒子密度は1.003〜2.600 g/ $\mathrm{cm}^{3}$ である.

\section{3. 室内実験による有機泥の侵入機構の解明}

\section{（1）下方向への有機泥の浸透による透水係数の低下 (1) 実験)}

下方向（重力方向）浸透流による混合水の浸透（有機 泥の残留）に伴う透水係数の低下比を図-5に示した. 透水係数はマノメーターで測定されたピエゾ水頭を用い てダルシー則（(1)式）により求めた。 また, 透水係数 の低下比は有機泥を浸透させてから各時刻の透水係数 $\left(k_{t}\right)$ と有機泥を浸透させる前の初期透水係数 $\left(k_{0}\right)$ と の比である.

$$
v_{s}=\frac{Q}{A}=k \frac{h_{L}}{L}
$$

ここに, $v_{s}[\mathrm{~cm} / \mathrm{s}]$ : 浸透流速, $Q\left[\mathrm{~cm}^{3} / \mathrm{s}\right]$ : 浸透流量, $A\left[\mathrm{~cm}^{2}\right]$ : 断面積, $k[\mathrm{~cm} / \mathrm{s}]$ : 透水係数, $L[\mathrm{~cm}]$ : 試料の長

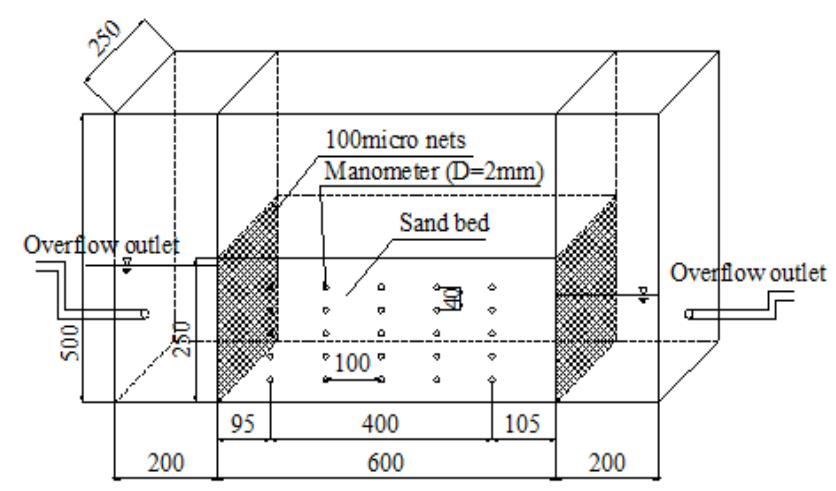

図-2＼cjkstart浸透実験に用いた装置の概略図（単位：mm）。

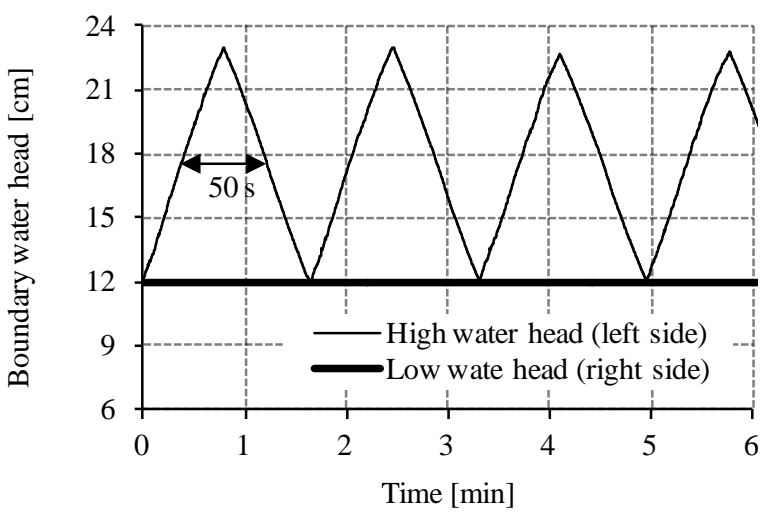

図-3＼cjkstart有機泥を浸透させる境界水位の条件（2実験）

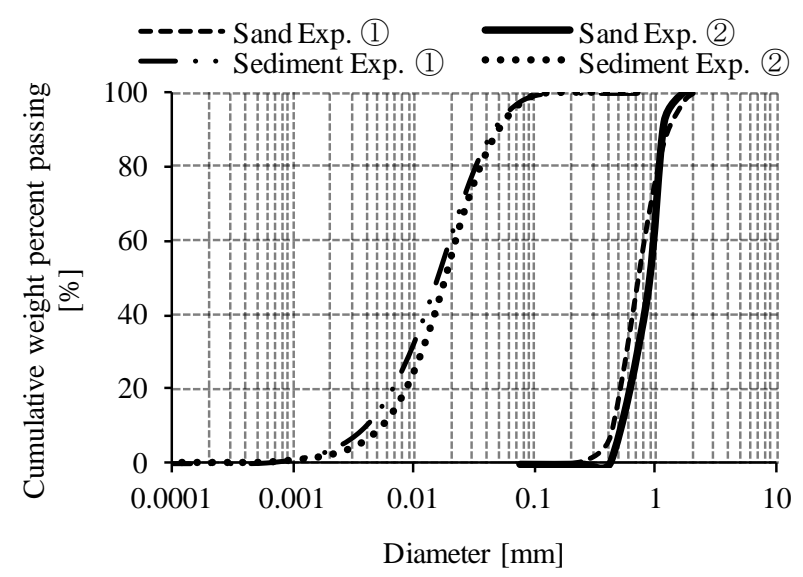

図-4＼cjkstart浸透実験に用いた砂および有機泥の粒度曲線.

さ, $h_{L}[\mathrm{~cm}]: L$ での圧力損失水頭である. (1)実験では, 初期の浸透流速は約 $0.064 \mathrm{~cm} / \mathrm{s}$ である.

図-5では, 砂柱全層 $(0-13 \mathrm{~cm})$ の透水係数の低下比 と比べて, 砂柱の表層 $(0-2 \mathrm{~cm})$ の透水係数の低下比が 大きいことから, 有機泥は砂柱に侵入直後から残留し, 表層に多く残留していることがわかる. さらに，砂柱内 での有機泥の残留量は有機泥の性状（表-2, C/N比）に 依存する9)ため, 混合水の下方向浸透に伴って間隙内に 有機泥が残留し, 砂柱の透水係数は異なる勾配で低下 している. C/N比の小さい有機泥は透水係数が高い砂柱 の深い場所まで浸透し, 砂層全体の透水係数を低下 
させていることがわかる.

\section{（2）逆方向浸透流による有機泥の流出機構（1)実験）}

図-5に引き続き（浸透開始から1時間後）行った水道 水の上方向浸透流による有機泥の流出に伴う透水係数の 増大を図-6に示した. 有機泥が残留した砂柱に水道水を 上方向に浸透させることで，砂柱内に残留した有機泥が 流出し，透水係数が回復していく(図-6)。しかし, 下浸透流を付与した水位差（表-2）より2倍程度（約 $10 \mathrm{~cm} ）$ の水位差で逆浸透流を生じさせても, 有機泥の 一部が砂柱に残り，砂柱の透水係数は初期状態に戻らな い. ちなみに，水位差の増大に伴う両実験の透水係数の 回復傾向が異なるのは, 有機泥の流出が有機泥の残留量, 有機泥の性状等に依存するためである。本実験結果は 潮汐により有機泥が侵入する場では周期的に起こる上下 方向の浸透流のみでは有機泥が砂地盤に残留し，透水性 が低下することを示唆するものである.

砂柱内浸透では，間隙形状に応じた流速差が生じる ため，粒子を浸透させる平均浸透流速が同じであっても 砂柱内に残留した粒子の動きは常に異なる．図-7には 上下方向浸透流における有機泥の残留・流出に伴う透水 係数の変化が示されている. 図-7から, 有機泥の侵入 方向と逆方向の浸透流によって砂柱下層（2１3 cm）の 透水係数の変化が小さいのに対して表層（0〜2 cm）の 透水係数の変化が大きく, 表層に残留した有機泥の一部 が掃流されたことが確認できる．本実験では有機泥を 流入させた水位差より小さい水位差（図-6中の○と○を 比較）で有機泥の侵入方向と逆方向の浸透流を付与して も，砂柱の表層に残留した有機泥の一部が流出可能で あるとわかった。

\section{(3) 周期的浸透流による圧力損失とピエゾ水頭との関係 (2) 実験)}

図-8には間隙水圧センサーで測定された上流側境界 水位 $(x=0 \mathrm{~cm})$, 砂層内でのピエゾ水頭 $(x=10$, $20 \mathrm{~cm} ）$ の変動が示されている．この図では，上流側 境界水位の変動速度 $(0.48 \mathrm{~cm} / \mathrm{s})$ に比べて砂層内での ピエゾ水頭の変動速度 $(x=10 \mathrm{~cm}: 0.45 \mathrm{~cm} / \mathrm{s}, x=20 \mathrm{~cm}$ : $0.43 \mathrm{~cm} / \mathrm{s}$ ) が遅く, ピエゾ水頭の変動振幅が小さいこと がわかる．これは，砂層内では浸透流によって圧力損失 が生じたためである。また，圧力損失は浸透長に比例 して大きくなり,$x=20 \mathrm{~cm}$ での圧力損失は $x=10 \mathrm{~cm}$ での 圧力損失に比べて大き $<, x=20 \mathrm{~cm}$ でのピエゾ水頭の 振幅はさらに小さくなる.

砂層内での圧力損失は砂層の透水係数（間隙率の 関数）に依存するため，ピエゾ水頭の振幅から砂層の 透水係数を推定できる. 有機泥が浸透する場においても 有機泥が残留すると砂層の透水係数が低下し，図-8に 示すよりもさらにピエゾ水頭の振幅が小さくなると予想 される. 言い換えれば，三次元の浸透場においても

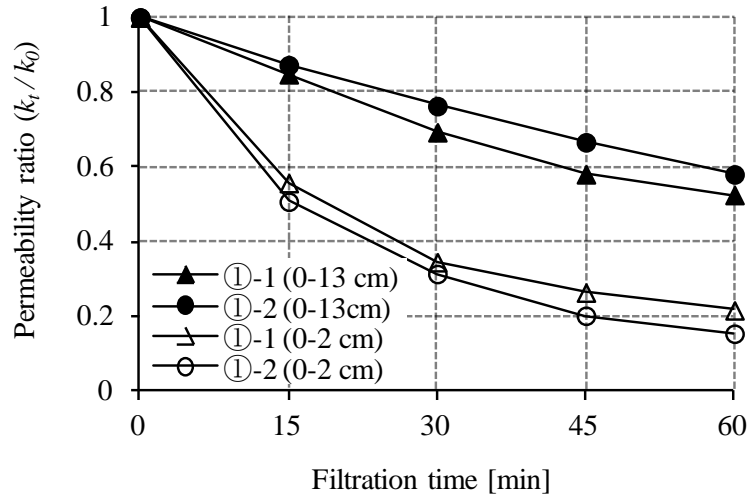

図-5＼cjkstart有機泥の下方向浸透に伴う透水係数の低下比.

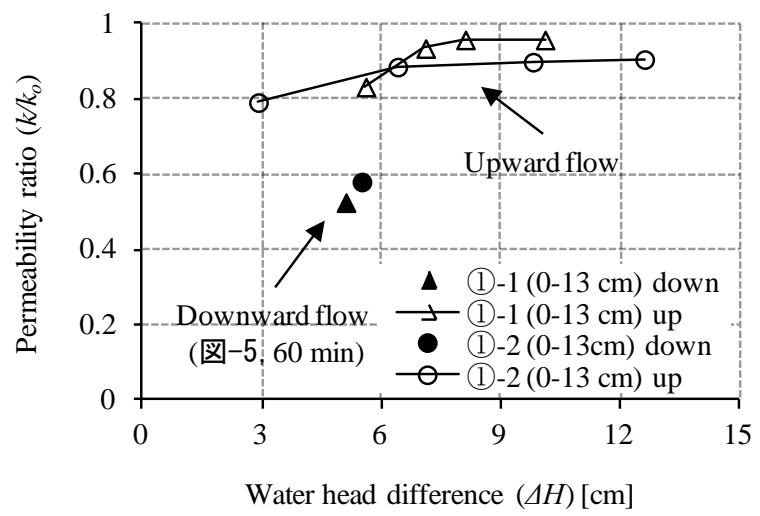

図-6＼cjkstart水道水の上方向浸透に伴う透水係数の増大

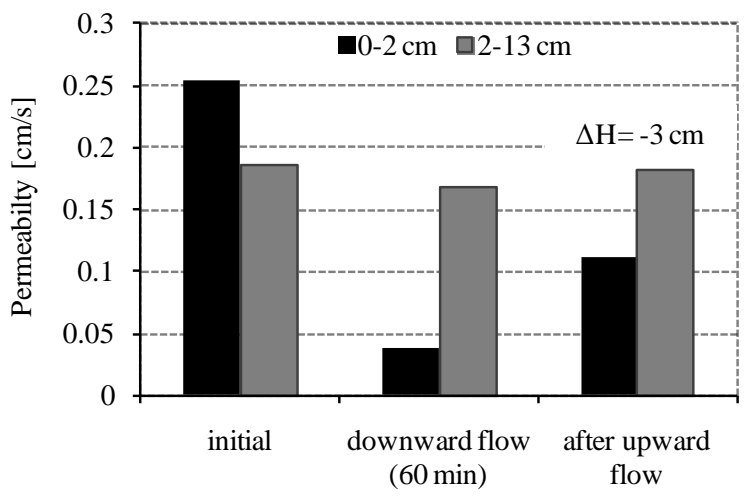

図-7 有機泥の残留・流出に伴う透水係数の变化 (実験(1)-2).

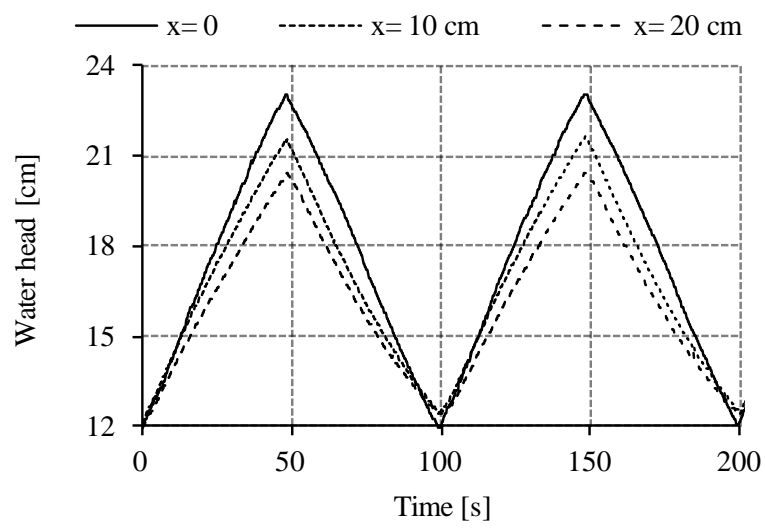

図-8＼cjkstart境界水位の変動に伴う砂層内ピエゾ水頭の変動 
一次元場と同様にピエゾ水頭から透水係数の変化を推定

し，有機泥の残留量を推定できると考えられる.

（4）水平方向にも浸透流がある砂層内でのピエゾ水頭の 再現（2)実験）

上流側境界水位に変動を与えて砂層内でのピエゾ水頭 の変動を再現して, 鉛直・水平方向に流速のある場での 有機泥の残留特性を検討する．ここでは，以下の仮定 (a)〜(d) に基づいてピエゾ水頭の再現を行う（図-9）.

(a) 砂層の初期透水係数は全断面で一様とした。初期 透水係数は定常状態（上流側境界水位が $23 \mathrm{~cm}$ および下流側境界水位が12 cm）での測定した浸透 流量と両境界の水位を用いてDupuit-Forchheimer式に より推定した.

(b) 図-8に示した上流側境界水位 $H_{0 t}(x=0)$ とピエゾ 水頭 $H_{x t}(\mathrm{x}=10,20 \mathrm{~cm})$ との差である圧力損失は浸透 流によって生じる。

(c) 砂層内での圧力損失は一次元浸透流下での圧力損失 式)に基づいた(2)式を用いて算出する.

$$
\frac{\Delta P}{L}=\frac{\rho g\left(H_{0 t}-H_{x t}\right)}{L}=\frac{72 \mu\left(1-n_{e}\right)^{2}}{D_{e}^{2} n_{e}^{3}} v_{s}
$$

ここに, $H_{x t}[\mathrm{~cm}]$ : 砂層内での各時刻のピエゾ水頭, $H_{0 t}[\mathrm{~cm}]$ : 各時刻の上流側境界水位, $\rho\left[\mathrm{g} / \mathrm{cm}^{3}\right]$ : 流体 の密度, $g\left[\mathrm{~cm} / \mathrm{s}^{2}\right]$ : 重力加速度, $\mu[\mathrm{g} / \mathrm{cm} / \mathrm{s}]$ : 粘性係数, $D_{e}[\mathrm{~cm}]$ : 砂粒子の体積平均粒径, $n_{e}$ : 有効間隙率, $v_{s}[\mathrm{~cm}]:$ 流線上の浸透流速, $L[\mathrm{~cm}]: v_{\mathrm{s}}$ での浸透距離, $\Delta P[\mathrm{dPa}]: L$ での圧力損失である. $n_{e}$ は直接に測定 できないため, 体積から求めた間隙率（表-2）を 計算に用いた。

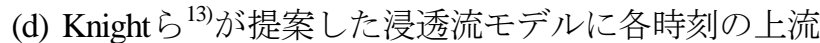
側境界水位と下流側境界水位を与えて, $v_{x t}(\mathrm{x}, \mathrm{y})$ と $v_{y t}(\mathrm{x}, \mathrm{y})$ の分布を算出した．本仮定では，鉛直方向へ の流速変化が1/1000オーダーであった（図-10）ため, 再現計算には $x$ 断面の流速は鉛直方向に平均した $v_{x t}(\mathrm{x})$ と $v_{y t}(\mathrm{x})$ を $v_{s}=\left\{\left[v_{x t}(\mathrm{x})\right]^{2}+\left[v_{y t}(\mathrm{x})\right]^{2}\right\}^{1 / 2}$ として 用いた．浸透距離 $L=\left(x^{2}+\Delta y_{t}^{2}\right)^{1 / 2}$ である.

図-11には $x=10,20 \mathrm{~cm}$ でのセンサーで測定された ピエゾ水頭と(2)式により推定されたピエゾ水頭との 比較が示されている，この図により，(2)式で推定され たピエゾ水頭が実測ピエゾ水頭とほぼ一致（最大相対 誤差が3\%）しており，実測ピエゾ水頭は(2)式で再現 できることがわかった．以上の結果から，鉛直平面内で の浸透場においても有機泥の浸透に伴う実測ピエゾ水頭 の変動を用いて(2)式から，間隙率の変化（残留量）が 推定できる. (2)式を(1)式に代入すると, 透水係数 $(k)$ が(3)式により求められ, 有機泥の残留に伴う透水係数 の変化が検討することが可能になる.

$$
k=\frac{1}{72} \frac{\rho g}{\mu} \frac{n_{e}^{3}}{\left(1-n_{e}\right)^{2}} D_{e}^{2}
$$

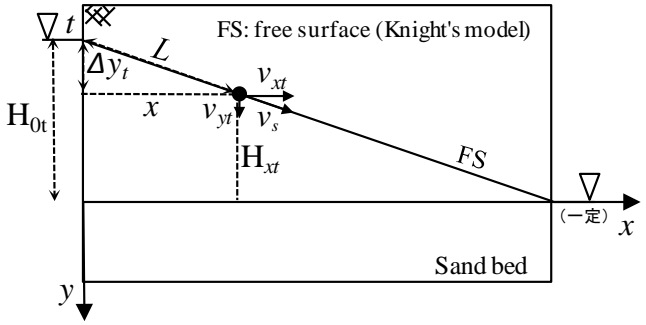

図-9 砂層内でのピエゾ水頭の算出方法

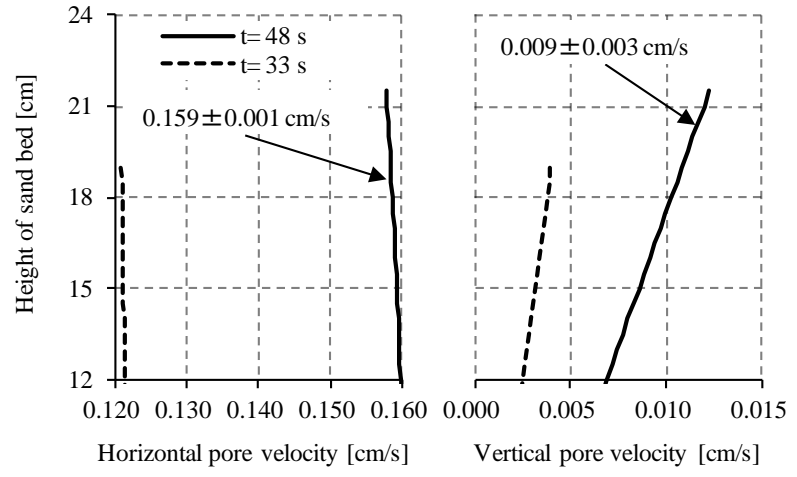

図-10 $x=10 \mathrm{~cm}$ 断面の間隙水流速の水平 - 鉛直分布. （上流水位 $20 \mathrm{~cm}(\mathrm{t}=33 \mathrm{~s}), 23 \mathrm{~cm}(\mathrm{t}=48 \mathrm{~s})$ ，下流水位 $12 \mathrm{~cm}$ )

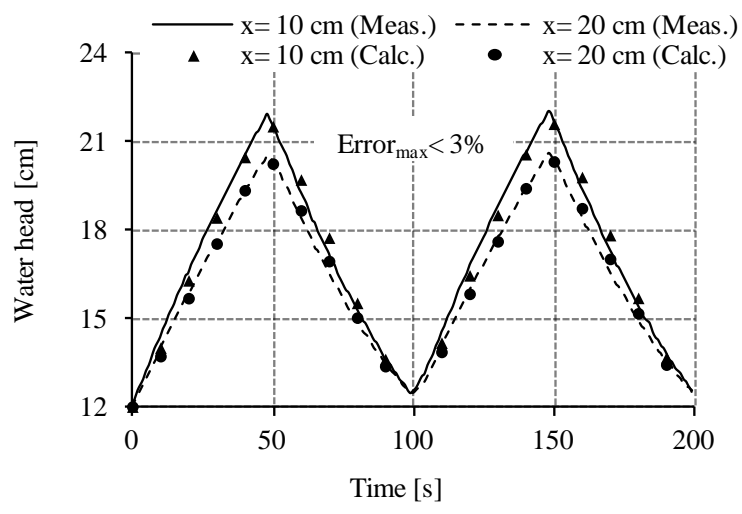

図-11＼cjkstart実測ピエゾ水頭と計算値（(2)式）との比較.

(5) 有機泥の残留に伴うピエゾ水頭の変化（2)実験）

有機泥の残留に伴う上流側境界水位 $(x=0)$ ）および $x=10 \mathrm{~cm}$ でのピエゾ水頭変動の経時変化を図-12に示し た. 浸透によって有機泥が残留すると間隙率が低下し, 圧力損失が増大寸る.この結果, 上流側境界水位の変動 に伴うピエゾ水頭の振幅は浸透時間の経過とともに小さ くなることが予測できる. 図-12中のピエゾ水頭 $(x=10 \mathrm{~cm})$ の変動振幅が経時的に小さくなることから, 砂層内での有機泥の残留量が浸透時間の経過とともに 増大していくことがわかる. 図-12の結果は逆浸透流に よって透水係数が完全に回復できない(1)実験の結果

（図-6）と同様の現象であり，有機泥を長時間で浸透 させると砂層の透水係数が低下していくことを示して いる. ただし, 流入断面付近では逆浸透流による有機泥 の流出（図-7）が生じることから，流入断面付近では 一方向の有機泥の浸透と比べて周期的に起こる上流側 


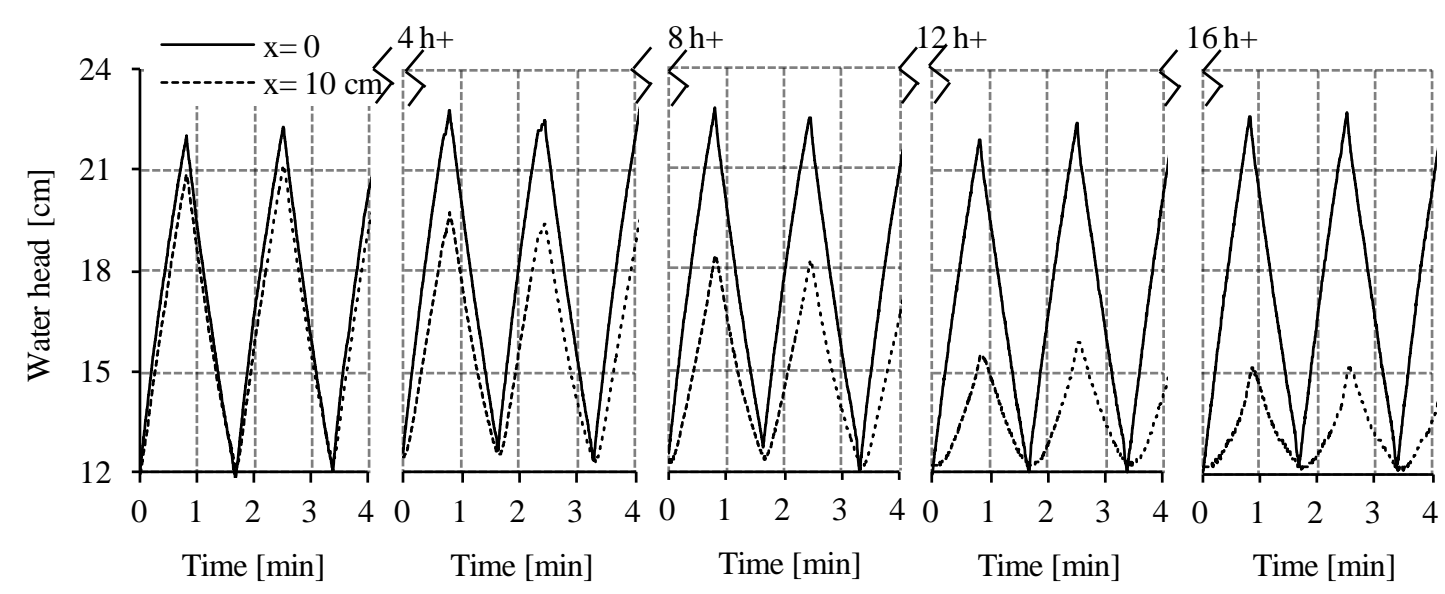

図-12 有機泥の残留によるピエゾ水頭の変化 $(x=10 \mathrm{~cm})$.

境界水位の低下に伴う逆浸透流による砂層の目詰まりの 抑制効果がある.

\section{4. まとめ}

本研究では, 有機泥の干潟地盤内への侵入機構を検討 すること目的として, 室内実験を行った. 得られた結果 を以下にまとめる.

(a) 周期的に起こる鉛直平面内での浸透場における砂層 内でのピエゾ水頭の変動は一次元圧力損失式を二次 元に拡張した提案式により相対誤差3\%以内で再現 できた.

(b) 提案式により間隙率を推定できるため, 有機泥の 浸透に伴う砂層内でのピエゾ水頭の変動を測定 すれば，砂層内での有機泥の残留体積を推測できる。

(c) 境界水位が振動すると流入断面付近では有機泥の 侵入方向と逆方向の浸透流が生じ, 有機泥の一部が 流出するため, 一方向の有機泥の浸透と比べて有機 泥の侵入による砂層の目詰まりの抑制効果がある.

謝辞 : 本研究は, 科学研究費補助金基盤研究 $\mathrm{B}$ (代表 者：日比野忠史），および日本学術振興会特別研究員奨 励費（代表者：トウ ナロン）による助成を受けた. ここに記して謝意を表する.

\section{参考文献}

1) Sontheimer, H.: Experience with riverbank filtration along the Rhine River, Journal AWWA, Vol. 72, No. 7, pp. 386-390, 1980.

2) Ryan, J.N. and Elimelech, M.: Colloid mobilization and transport in groundwater, Colloids and Surfaces A: Physicochemical and Engineering Aspects, Vol. 107, pp. 1-56, 1996.

3) 日比野忠史, 保光義文, 福岡捷二, 水野雅光 : 洪水に伴う 河口干潟環境と生物生息の変化, 河川技術論文集, 第12巻, pp. 431-436, 2006.

4) Sinton, L.W., Noonan, M.J., Finlay, R.K., Pang, L. and Close,
M.E.: Transport and attenuation of bacteria and bacteriophages in an alluvial gravel aquifer, New Zealand Journal of Marine \& Freshwater Research, Vol. 34, No. 1, pp. 175-86, 2000.

5) Kim, B.S. and Corapcioglu, M.Y.: Contaminant transport in riverbank filtration in the presence of dissolved organic matter and bacteria: a kinetic approach, Journal of Hydrology, Vol. 266, pp. 269-283, 2002.

6) Bekhit, H.M., El-Kordyand, M.A. and Hassan, A.E.: Contaminant transport in groundwater in the presence of colloids and bacteria: Model development and verification, Journal of Contaminant Hydrology, Vol. 108, pp. 152-167, 2009.

7) Touch, N., Nakashita, S. and Hibino, T.: Deposition behavior of mud in sand beds under the effects of organic properties, Transport in Porous Media, Vol. 91, pp. 531-546, 2012.

8) TOUCH NARONG, 駒井克昭, 中下慎也, 日比野忠史 : 砂層内での有機微細粒子の移動に関する実験的な研究, 土 木学会論文集B2 (海岸工学), Vol. 66, No. 1, pp. 1076-1080, 2010.

9) TOUCH NARONG, 中下慎也, 小枝豪志, 日比野忠史 : 砂層内における有機泥の移動に及ぼす有機物の性状, 水工 学論文集, 第55巻, pp. 1681-1686, 2011.

10) TOUCH NARONG, 中下慎也, 小枝豪志, 日比野忠史 : 砂層内における有機泥の輸送に及ぼす浸透流量と間隙体積 の効果, 土木学会論文集B2 (海岸工学), Vol. 67, No. 2, pp. 971-975, 2011.

11) TOUCH NARONG, 中下慎也, 日比野忠史 : 砂層間隙内 における有機泥の残留で低下寸る透水係数の推定モデル, 土木学会論文集B1(水工学), Vol. 68, No. 4, pp. 547-552, 2012.

12) TOUCH NARONG, 中下慎也, 小枝豪志, 日比野忠史 : 砂地盤における地下水流れで浸透する有機泥の残留モデル， 土木学会論文集B2(海岸工学), Vol. 68, No. 2, pp. 1086-1090, 2012.

13) Knight, J. H.: Improving the Dupuit-Forchheimer groundwater free surface approximation, Advances in Water Resources, Vol. 28, pp. 1048-1056, 2005.

(2012. 9. 30受付) 